\title{
Az atopy patch teszt szerepe az atopiás dermatitis diagnózisában
}

\section{Role of atopy patch test in the diagnosis of atopic dermatitis}

\author{
PARAGH LILLA DR., NAGY LINDA DR., JANKA ESZTER, GÁSPÁR KRISZTIÁN DR., \\ REMENYIK ÉVA DR., SZEGEDI ANDREA DR., IRINYI BEATRIX DR.
}

\begin{abstract}
DE Klinikai Központ Bőrgyógyászati Klinika, Bőrgyógyászati Allergológiai Tanszék, Debrecen
\end{abstract}

\section{ÖSSZEFOGLALÁS}

Az atopiás dermatitis $(A D)$ prevalenciája növekvó tendenciát mutat a fejlett országokban. Számos környezeti faktor provokálja és rontja a tüneteket, közülük kiemelendö az aeroallergének szerepe, a betegek szenzitizáltsága Atopy patch teszttel (APT) vizsgálható.

Célunk az aeroallergén szenzibilizáció és jellemzö allergének felmérése 46 (24 nö, 22 férfi) AD-s betegböl álló vizsgálati csoportban APT-vel, valamint a Prick teszt és specifikus IgE szinttel mutatott korrelációval. APT-vel nagyarányú szenzibilizációt detektáltunk a vizsgált betegek között. A vizsgálati csoportban legnagyobb mértékben pollenek és háziporatka esetében igazoltunk szenzibilizációt, ami tükrözte az irodalmi adatokban közölteket. Súlyosság szerinti megoszlásban nem találtunk jelentôs eltérést feltehetöen az alacsony betegszám miatt, de ezen a területen kevés a korábban végzett tanulmány is. Pozitív korrelációt APT és Prick teszt között, valamint Prick teszt és spec. IgE meghatározás között Dermatophagoides pteronyssinus (D. pter.) esetében találtunk. A jövőben fontos nagyobb betegszámot felvonultató vizsgálatok folytatása, a különböző súlyosságú $A D$-s tünetekkel rendelkezö betegek szenzibilizáltságának összehasonlítása.

\section{Kulcsszavak:}

\section{atopy patch teszt - aeroallergén szenzitizáció} - atopiás dermatitis - korreláció

\section{SUMMARY}

Atopic dermatitis ( $A D)$ has been showing an increasing tendency in prevalence in developed countries. Symptoms are provoked and exacerbated by aeroallergens. The role of these aeroallergens and sensitization of patients can be examined by atopy patch test (APT). We wanted to find out the frequency of aeroallergen sensitization and the prevalence of the specific allergens in a group of 46 (24 female, 22 male) AD patients. We also wanted to see the correlation between APT, Prick test and specific IgE test. We had observed a high level of sensitization with APT among our group of patients, most common allergens causing sensitization were pollens and house dust mite, which resemble the data of previous studies. We did not observe significant difference between the groups devided according to the severity of $A D$, most likely due to the low number of patients enrolled in the study. Positive correlation was found between APT and Prick test and nonetheless between Prick test and specific IgE levels in case of Dermatophagoides pteronyssinus. In the future it is important to conduct further studies which include lager number of patients and investigate the differences between sensitization of $A D$ patients belonging to different subgroups based on severity of clinical symtoms.

\section{Key words: atopy patch test - aeroallergen sensitization - atopic dermatitis - correlation}

Az atopiás dermatitis (AD) intermittáló megjelenésú, krónikus lefolyású, veleszületett allergiás hajlam alapján kialakuló, poligénes, gyakran több provokáló faktor által aktivált bórgyulladás, amely sok esetben már csecsemôkorban jelentkezik. Általában magas IgE szinttel, illetve más I-es típusú hyperszenzitivitási reakción alapuló betegségekkel (asthma bronchiale, allergiás rhinitis, ételallergia, stb.) kombinálva jelentkezhet (1). Jellemzője a fokozott bőrreaktivitás, az életkor-függő megjelenés, a gya- kori fellángolások, az ekcémás tünetek jellegzetes lokalizációja, a száraz bőr, a kínzó viszketés, az egyéni vagy családi atopiás anamnézis és a szekunder infekciók gyakori jelenléte. Európában a gyerekek 10-20\%-át érinti, a felnőtt populációban $1 \%$ gyakorisággal fordul elő (2). Hazánkban a gyerekek közel 17\%-a szenved atopiás ekcémában $(3,4)$. Az AD multifaktoriális betegség, patogenezise komplex, kialakulásában számos tényezô játszik szerepet. Öröklött tényezők (bőr barrier funkcióinak károso-

Levelező szerzô: Dr. Paragh Lilla, DE Klinikai Központ Bốrgyógyászati Klinika, Bôrgyógyászati Allergológiai Tanszék, Debrecen e-mail: paraghlilla@yahoo.com 
dása (fillagrin mutáció), a kórosan múködő veleszületett és szerzett immunrendszer, neurovegetatív idegrendszer eltérése) és számos környezeti faktor (allergének, irritáló tényezők, fertőző ágensek) szerepelhet etiológiai tényezőként $(5,6)$. Újabb kutatások felvetik autoimmun folyamatok szerepét is a betegség kialakulásában (7).

$\mathrm{Az}$ AD-ben szenvedő betegeket két csoportra lehet osztani: extrinsic és intrinsic típusra. Az extrinsic AD-re (EAD) jellemző az emelkedett szérum totál IgE szint, specifikus IgE jelenléte a vérben, pozitív bőrtesztek, míg az intrinsic formában, bár a klinikai tünetek hasonlóak az EAD tüneteihez, nem mutatható ki fokozott I. típusú hyperszenzitivitásra való hajlam $(8,9)$, nincs jelen légúti vagy táplálék allergia, a betegek szérum IgE szintje normál tartományban van, nem detektálható specifikus IgE, és a bőrtesztek is negatívak (10). A nem allergiás, intrinsic AD (IAD) előfordulását 16-45\%-ra becsülik a teljes AD-es populáción belül az egyes vizsgálatok (9).

$\mathrm{Az} \mathrm{AD}$ diagnózisának alapját az anamnézis és a klinikai tünetek képezik a Hanifin-Rajka kritériumrendszer szerint, mely major és minor kritériumokat differenciál a betegség jellegzetességei között (11). Szövettani, illetve laboratóriumi vizsgálatok nem szükségszerúek a kórkép felállításához, de segíthetik azt.

A részletes kivizsgálás része a gondos anamnézis felvétel, az alapos fizikális vizsgálat (inspekció, dermographismus), a laboratóriumi tesztek (kvalitatív vérkép, LDH, szérum totál IgE, specifikus IgE), bőr barrier funkciójának vizsgálata (Transepidermális vízvesztés mérés), illetve a bőrtesztek (Prick teszt, atopy patch teszt) elvégzése.

Az AD-s betegek szenzitizáltságának vizsgálata során a már régóta alkalmazott Prick teszt és szérum specifikus IgE meghatározások mellett egyre inkább alkalmazásra kerül az APT, amely - az epicutan teszt által vizsgált inorganikus allergénektôl eltérően - elsősorban az inhalatív vagy nutritív allergének ekcematózus bőrtüneteket kiváltó valós hatását mutatja meg.

\section{Célkitúzés}

Célul tűztük ki a Debreceni Egyetem Klinikai Központ Bőrgyógyászati Klinika Bőrgyógyászati Allergológiai Tanszékén gondozott AD-ben szenvedô betegek tüneteit provokáló faktorok vizsgálatát az APT segítségével. Értékeltük az aeroallergén szenzibilizáció arányát és a jellemző allergének megjelenését a gondozott betegcsoportban, a demográfiai adatokkal, a bőrtünetek klinikai súlyosságával, a kórcsoportokkal, valamint az EAD, illetve IAD betegcsoport jellegzetességeivel összefüggésben. Vizsgáltuk a korrelációt az APT, a Prick teszt, illetve a specifikus IgE teszt eredményei között.

\section{Anyag és módszer}

A DE Klinikai Központ Bốrgyógyászati Klinika Allergológiai Szakrendelésén 2010. szeptember - 2012. február időintervallumban AD diagnózisával gondozott 46 beteget vizsgáltunk, akiknél ezen idő alatt APT mellett Prick teszt, szérum totál IgE és specifikus IgE meghatározás történt részletes tájékoztatás és a betegtájékoztató és beleegyező nyilatkozat aláírását követően. Az AD diagnózisának felállítása a Hanifin-Rajka kritérium rendszer szerint történt, amely szerint legalább 3 major, illetve legalább 3 minor kritériumnak kellett teljesülnie (11)

Az AD súlyossága a Scoring Atopic Dermatitis index (SCORAD) alapján került meghatározásra $(12,13)$. A betegeket SCORAD értékek szerint: enyhe (18 alatt), mérsékelt (18-35), közepesen súlyos (35-60) és súlyos (60 felett) klinikai tüneteket mutató csoportba soroltuk.

Az anamnézis felvétele során az esetleges egyéb atopiás megbetegedések (rhinitis, conjunctivitis, asthma) társulását is vizsgáltuk.

Az APT-t klinikánkon az European Task Force on Atopic Dermatitis (ETFAD) által standardizált protokoll alapján végeztük és értékeltuik, mely során tünetmentes, kezeletlen hát bőrére helyeztük fel az allergéneket (Spiromed tesztsor) paravertebralisan $12 \mathrm{~mm}$-es Finn kamra segítségével (14). Az alkalmazott allergének a következők voltak: 1. Dermatophagoides pteronyssinus 2. Dermatophagoides farinae 3. Kutya epithel 4. Macska epithel 5. Fükeverék 6.Réti komócsin 7. Útifü 8. Nyírfa 9. Fekete üröm 10. Csomós ebír. A teszthez standardizált allergénkoncentrációkat használtunk (5000-7000 PNU/g vagy $200 \mathrm{IR} / \mathrm{g}$ ) vazelinben oldott formában. Az allergén tesztsor felhelyezés 48 órás okklúzióban zajlott, a teszt kiértékelése 20 perc, 24, 48, majd 72 óra elteltével történt, az EFTAD által megadott skála szerint. A teszt ideje alatt, valamint antihisztamin esetében az azt megelőző 4 napban, szisztémás kotrikoszteroid esetében a megelőző 4 hétben gyógyszerhasználat nem történt (15).

A Prick tesztet az alkar tünetmentes bőrére helyeztük fel pozitív (10ìg/ml hisztamin) és negatív $(0,9 \% \mathrm{NaCl})$ kontroll mellett.

$\mathrm{Az}$ allergén-specifikus IgE antitestek szérum koncentrációjának meghatározása szilárdfázisú immunoassay-vel történt a Debreceni Egyetem Klinikai Központ Laboratóriumi Medicina Intézet által.

A szérum totál IgE koncentráció esetén vizsgálatunkban 120 kU/L feletti értéket tekintettük emelkedettnek.

A statisztikai analízist az IBM SPSS Statistics program segítségével végeztünk. Lineáris korrelációszámítást alkalmaztunk, amely két változó közti kapcsolatot, illetve annak erősségét vizsgálta.

\section{Eredmények}

Demográfiai adatok (életkor, nemek szerinti megoszlás, súlyosság, egyéb atopiás betegségek jelenléte)

A vizsgálatba bevont $46 \mathrm{AD}$-ben szenvedő beteg átlagéletkora 22,2 (9-53 éves) év volt. A 46 beteg 52,18\%-a volt nô. A 18 éven aluli volt a betegek 30\%-a. A tanulmányban a betegekről a gyermekkori-, ill. a felnőttkori AD típus jellegzetességeit írhattuk le.

A betegek átlag SCORAD értéke 47,5 (18-76) volt. A klinikai súlyosság tekintetében az AD diagnózisának felállításakor kapott SCORAD értékek alapján az enyhe bőrtünetekkel rendelkező csoportba egy beteg sem került. Mérsékelten súlyos kategóriába betegeink 23,92\%-a (10 beteg) tartozott, közepesen súlyos 56,52\% (27 beteg), súlyos kategóriába betegek 19,56\%-a (9 beteg) került.

Az EAD csoportba a betegek 84,7\%-a tartozott, akiknek anamnézisében allergiás rhinitis vagy asthma bronchiale szerepelt, vagy szérum totál IgE szintjük meghaladta a 120 $\mathrm{kU} / \mathrm{L}-\mathrm{t}$ vagy specifikus IgE pozitivitást észleltünk. A vizsgált beteganyagban a betegek 2/3-ánál volt megfigyelhető egyéb atopiás megbetegedés (33,3\%-ban csak allergiás rhinitis, $12,8 \%$-ban csak asthma, 17,9\%-ban asthma és rhinitis allergica együttesen, 2,5\%-ban rhinoconjunctivitis).

\section{APT eredmények}

APT-vel korai választ (20 perces leolvasásnál) nem észleltünk egy betegnél sem. Késői pozitivitást (48 órás, 72 órás leolvasásnál) a 46 beteg 63\%-ánál (29 beteg) tapasz- 


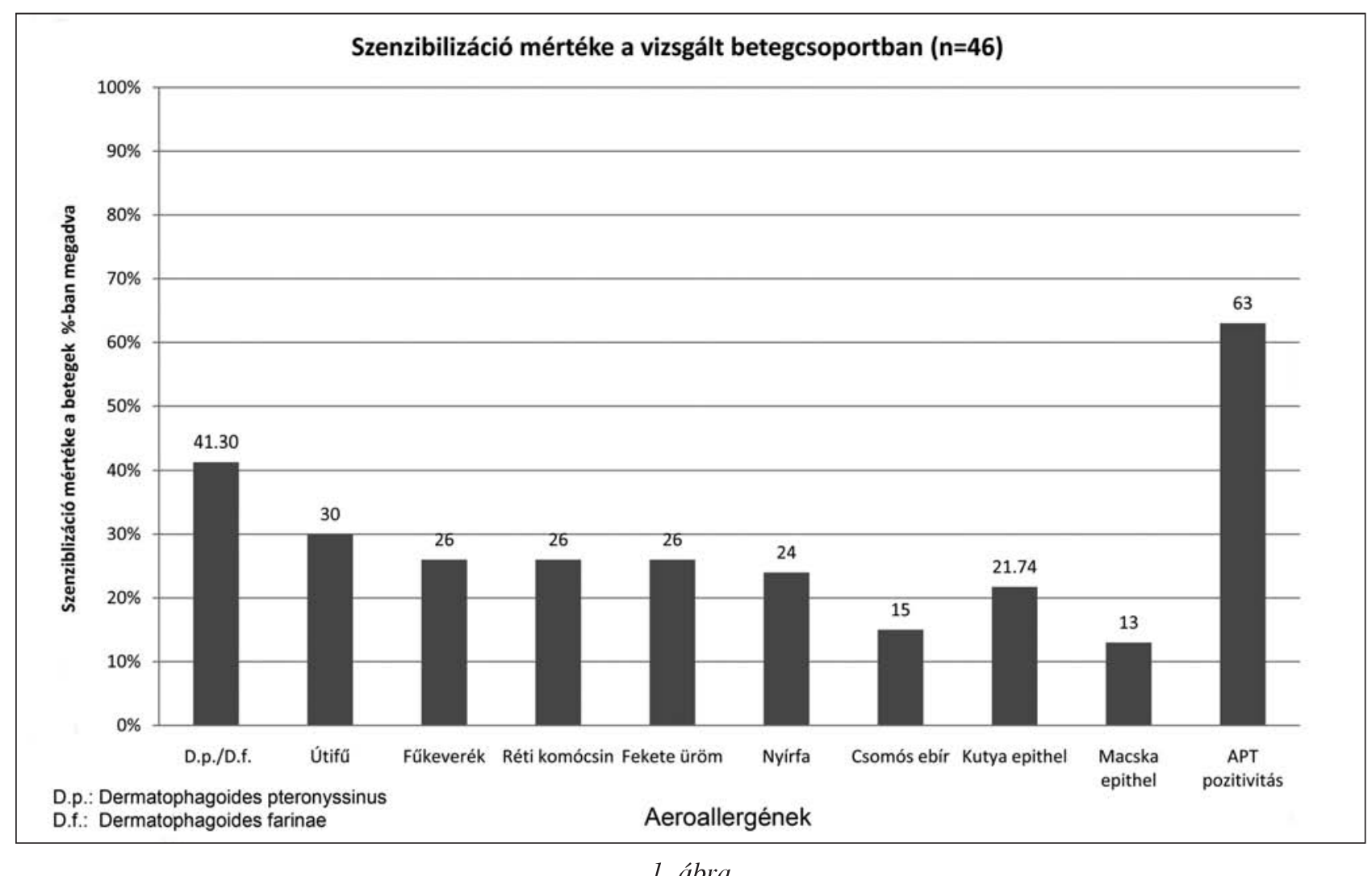

Szenzibilizáció mértéke a vizsgált betegcsoportban $(n=46)$

taltunk. 28 pozitív választ adó beteg az EAD csoportból került ki, 1 pedig a kiindulási IAD csoportból. A további adatokat a teljes betegcsoportra számolva adjuk meg.

Állati hámra 28,26\%-ban kaptunk pozitivitást. Három beteg mind kutya, mind macska epithelre mutatott pozitivitást. A kutya hámszövet esetében $21,74 \%$-os szenzibilizációt láttunk, macska epithel esetében a szenzibilizáció mértéke 13\%-os volt. A háziporatka szenzibilizáció 41,3\%-os volt. Egy vagy több pollenre a szenzibilizáció $54,34 \%$-os volt. Pollenek közül a leggyakoribb az útifú szenzibilizáció $30,4 \%$-kal, a fúkeverék $26 \%$, a réti komócsin $26 \%$, ugyanígy a fekete üröm szenzibilizáció gyakorisága is $26 \%$, majd csökkenő gyakorisággal következett a nyírfa 24\%-kal és a csomós ebír szenzibilizáció 15,2\%-kal (1.ábra).

A mérsékelten súlyos SCORAD értékkel rendelkezők csoportjában $63,6 \%$-os volt az APT által detektált pozitivitás, közepesen súlyos SCORAD esetében ez az érték $61,5 \%$, a súlyos SCORAD csoportban $66,6 \%$ volt. Legnagyobb mértékben háziporatkával és pollennel szembeni szenzibilizációt észleltünk. A mérsékelten súlyos csoportban a háziporatka szenzibilizáció 45,45\%-os volt, a közepesen súlyos csoportban $34,6 \%$, a súlyos csoportban $55,5 \%$ volt. A pollen szenzibilizáció a mérsékelt, a közepesen súlyos és a súlyos csoportban rendre 54,5\%, 53,8\% és $55,5 \%$ volt. A kapott értékek nem mutattak szignifikáns különbséget.

A 18 éven felüliek esetén 65,6\%-ban, 18 éven aluliak esetében $57,4 \%$-ban észleltünk pozitivitást valamely allergénre. A 18 éven felüliek között 40,6\%-os szenzibilizációt mutattunk ki háziporatkára, 15,6\%-ban macska epithelre, 28,1\%-ban kutya epithelre és 59,4\%-ban pollenre. Ezzel szemben a 18 éven aluliak közül a szenzibilizáció háziporatka esetében $42,8 \%$, kutya epithel esetében $7,1 \%$, macska epithel esetében szintén $7,1 \%$, valamint pollen esetében $42,8 \%$ volt (2. ábra). A kutya epithel szenzibilizáció a 18 év feletti korcsoportban szignifikánsan magasabb volt $(\mathrm{p}=0,0005)$. Vélhetôen az alacsony betegszám miatt pollen és macska epithel esetében nem találtunk szignifikáns különbséget a 18 éven felüli és 18 éven aluli korcsoport között.

Vizsgálati anyagunkban a nôk 66,7\%-a mutatott APT pozitivitást. Nők között a háziporatka szenzibilizáció $37,5 \%$-os, a pollen szenzibilizáció $62,5 \%$-os, a macska epithel $12,5 \%$-os és a kutya epithel $20,8 \%$-os volt. Férfiak esetében $59 \%$-uk mutatott pozitív reakciót. A férfiak között 45,45\%-os szezibilizációt láttunk háziporatka és pollen esetében, míg macska epithel esetében 13,6\%-ban és kutya epithel 22,7\%-ban volt pozitív (2.ábra). Szignifikáns különbséget az allergének nemek szerinti eloszlásában nem igazoltunk feltehetően az alacsony betegszám miatt.

A betegek 56,5\%-a esetében társult más atopiás betegség az AD mellé. Az egyéb atopiás betegséggel rendelkezők csoportjában az APT-vel kimutatott szenzibilizáció 69\%-os volt, míg a más allergiás betegséggel nem rendelkezők csoportjában ez az érték csupán 55\%-os volt. Szignifikáns különbséget nem láttunk felthetően az alacsony betegszám miatt. Az egyéb atopiás betegségben szenvedők csoportjának 42,3\%-a nő, 57,7\%-a férfi volt, 34,6\%-a 18 év alatti, $65,4 \%$-a 18 év feletti volt. 


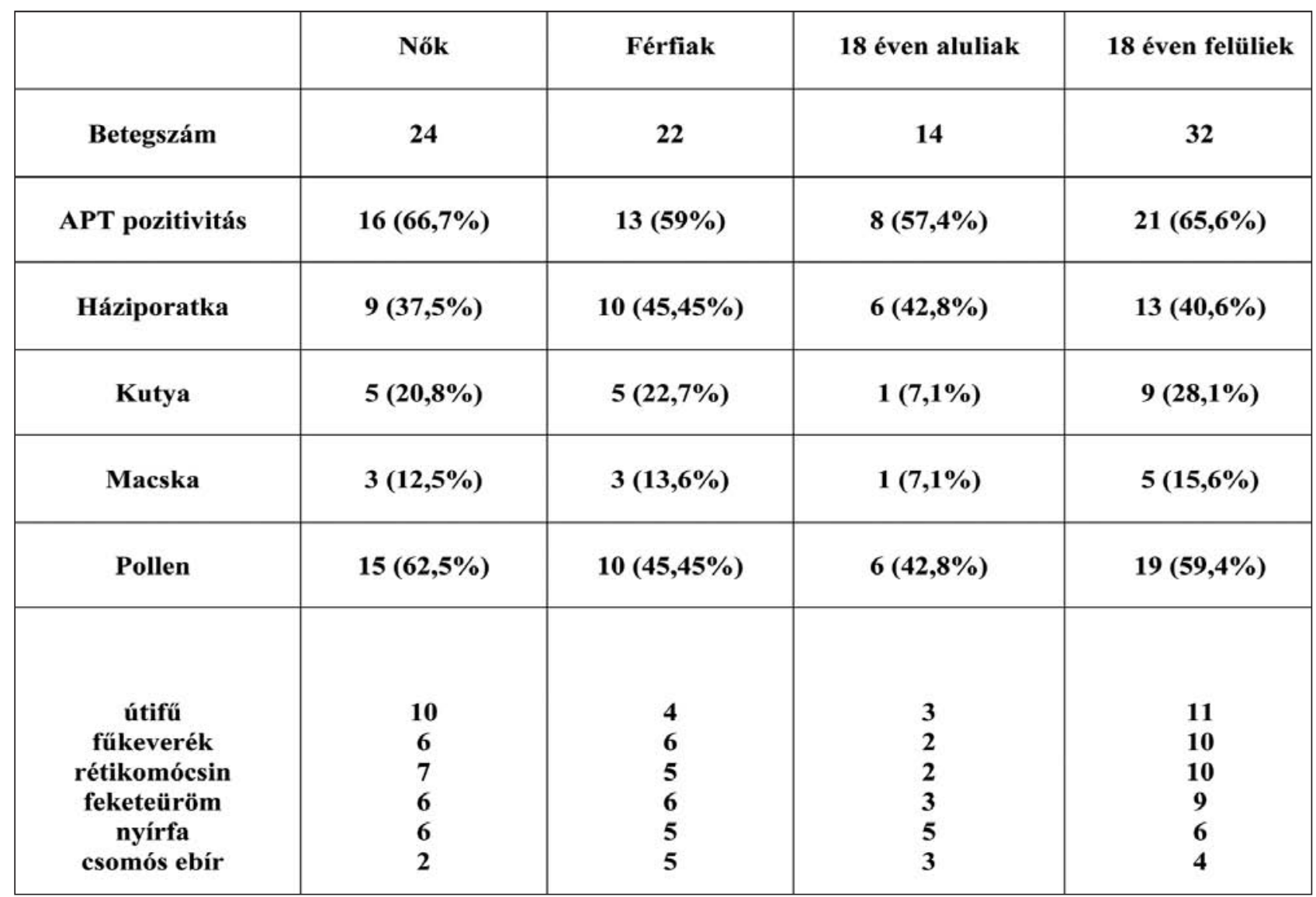

2. ábra

Pozitív APT-t mutató betegek száma és \%-a a vizsgált demográfiai csoportok szerint (n=46)

Korreláció az APT, valamint a Prick teszt, illetve a specifikus IgE teszt eredményei között

A vizsgált 46 beteg közül 63\%-ban (29 beteg) kaptunk pozitív eredményt APT-vel. Az APT-vel pozitív választ mutató 10 allergén esetében 6 allergénnél találtunk összesen 26 esetben pozitivitást Prick teszttel és 6 allergén esetében 22 alkalommal láttunk pozitivitást specifikus IgE meghatározás során.

APT-vel 19 betegnél (41,3\%-ban) tudtunk kimutatni háziporatka szenzibilizációt. A 19 betegból 10-nél tapasztaltunk pozitivitást mind Prick teszttel, és mind specifikus IgE meghatározással, 2 esetben csak specifikus IgE pozitivitást láttunk APT pozitivitás mellett, 4 esetben pedig csak Prick teszt pozitivitás társult az emelkedett IgE szinthez.

A macska epithel esetében 6 betegnél (13\%-ban) detektáltunk pozitív eredményt APT-vel. A 6 beteg esetében 1nél találtunk mindhárom teszttel pozitivitást, az APT pozitivitáshoz 1 betegnél csak pozitív Prick teszt és 2-nél pedig csak pozitív specifikus IgE eredmény társult.

A pollenek esetében 54,34\%-ban igazoltunk APT-vel pozitív reakciót. Mindhárom teszttel ugyanarra az allergénre 1betegnél mutattunk ki (fúkeverék) szenzibilizációt, APT mellett csak specifikus IgE meghatározással ugyanarra az allergénre 3 esetben ( 2 feketeüröm, 1 útifú), Prick teszttel pedig 5 esetben (fúkeverék 2, feketeüröm 2, nyírfa 1) észleltünk pozitivitást.
Kutya epithel esetében 21,47\%-os szenzibilizációt igazoltunk APT-vel. Mindhárom teszttel pozitivitást 2 esetben kaptunk. APT-hez 1-1 esetben társult vagy Prick teszt vagy specifikus IgE pozitivitás.

A kapott eredmények alapján elmondhatjuk, hogy a pollenek esetében adott allergéneket vizsgálva, valamint kutyaszőr és macska epithel esetében nem találtunk megfelelő pozitív korrelációt a Prick teszt, APT és specifikus IgE meghatarozás között, feltehetően az alacsony betegszám miatt. Azonban a Dermatophagoides pteronyssinus esetében közepesen erôs pozitív korrelációt mutattunk ki az APT és a Prick teszt ( $\mathrm{p}=0,002, \mathrm{R}=0,372)$ között, valamint a Prick teszt és specifikus IgE meghatározás között $(\mathrm{p}=0,005, \mathrm{R}=0,355)$ (3. ábra).

\section{Megbeszélés}

$\mathrm{Az} \mathrm{AD}$ egy krónikus lefolyású, remisszióval és relapszusokkal jellemezhető, genetikailag meghatározott, több környezetei faktor által provokált, kínzóan viszkető gyulladásos bőrbetegség. Az inhalatív allergének által kiváltott, IgE mediált kontakt reakció fontos patogenetikai tényező az AD kialakulásában. Az IgE mediált inhalatív allergének epicutan tesztelése jól reprodukálhatóan kivitelezhető APT során.

Aeroallergénekkel végzett epicutan tesztek eredményeit 1937-ben Rostenberg és Sulzberger publikálták 


\begin{tabular}{|c|c|c|c|c|}
\hline \multicolumn{2}{|c|}{ Dermatophagoides pteronyssinus } & APT & Prick teszt & Specifikus IgE \\
\hline \multirow{3}{*}{ APT } & Pearson korreláció & 1 & .372 & .205 \\
\hline & $\begin{array}{l}\text { Szignifikancia } \\
\text { (2-tailed) }\end{array}$ & & .002 & .097 \\
\hline & $\mathrm{N}$ & 114 & 69 & 67 \\
\hline \multirow{3}{*}{ Prick teszt } & Pearson korreláció & .372 & 1 & .355 \\
\hline & $\begin{array}{l}\text { Szignifikancia } \\
\text { (2-tailde) }\end{array}$ & .002 & & .005 \\
\hline & $\mathrm{N}$ & 69 & 80 & 62 \\
\hline \multirow{3}{*}{ Specifikus IgE } & Pearson korreláció & .205 & .355 & 1 \\
\hline & $\begin{array}{l}\text { Szignifikancia } \\
\text { (2-tailed) }\end{array}$ & .097 & .005 & \\
\hline & $\mathrm{N}$ & 67 & 62 & 87 \\
\hline
\end{tabular}

3. ábra

Korrelációs kapcsolat háziporatka esetében az APT, Prick teszt, specifikus IgE pozitivitás között

( $\mathrm{R}=$ Pearson-féle korrelációs együttható)

először (16). Mitchell és mtsai azt találták vizsgálatukban, hogy az aeroallergének epicutan alkalmazása ekcémás reakciókat provokál olyan betegeknél, akik korábban ugyanarra az allergénre azonnali típusú bőrreakciót mutattak (17).

1988-ban Adinoff és mtsai 10 AD-s beteg vizsgálata során késői reakciót észleltek háziporatkára, pollenekre, állati epithelekre és penészre. A pozitív reakciók jelenléte korrelációt mutatott a betegek anamnézisével. Eredményeik alapján felvetették az aeroallergének AD-t provokáló szerepét és a bôrtünetek kialakulásában mind az azonnali, mind a késői típusú túlérzékenységi reakcióknak jelentőséget tulajdonítottak (18). Későbbi kutatásaikban olyan $\mathrm{AD}$-s betegen végeztek aeroallergénekkel epicutan teszteket, akik korábban aeroallergénekkel pozitív reakciót mutattak Prick teszt során. Az epicutan tesztek helyén 48 és 72 órában észlelt késői, ekcémaszerû reakciók szorosan korreláltak a betegek anamnézisével, illetve saját megfigyeléseikkel, melyek szerint bizonyos körülmények között bőrtüneteik fellángoltak. A pozitív reakciót adó aeroallergének kerülése bőrállapot-javulást eredményezett csaknem valamennyi betegnél (19). 1989-ben Ring és mtsai dolgozott ki az AD-s betegek bőrtüneteit provokáló inhalatív allergének szenzibilizáló hatásának kimutatására egy módszert, amit ,,atopy patch test"-nek neveztek el (20). Ezután több száz betegen standardizálták a módszert (21), és kimutatták, hogy az APT specificitása sokkal magasabb (60-90\%), mint a Prick tesztté, míg szenzitivitása 56-75\%, reprodukálhatósága 90\% körüli.
Az általunk vizsgált 46 AD-s beteg 63\%-ánál észleltünk késői pozitivitást az APT-ben. Irodalmi adatok alapján vegyes életkorú AD populációnál 39-96,7\% között változik a pozitív reakciók gyakorisága APT-ben $(21,22,23)$, mely jól korrelál saját eredményeinkkel (4. ábra). A nók $66,7 \%$-a, a férfiak 59\%-a volt szenzibilizált valamelyik aeroallergén által.

Az aeroallergén szenzibilizáció gyakoriságával kapcsolatos irodalmi adatok fóleg a 18 év alatti AD-s betegcsoportra, illetve vegyes életkorú $\mathrm{AD}$-s betegekre vonatkoznak. A felnőtt AD-s betegcsoporton végzett vizsgálatokról igen kevés adat áll rendelkezésre, mivel a betegség leginkább a gyermekkor sajátja, és prevalenciája az életkor előrehaladtával csökken.

Darsow és mtsai több alkalommal is végeztek vizsgálatokat az AD és az APT kapcsolatáról. 1999-ben egy 253 főből álló, vegyes életkorú (15-63 év, 197 nő és 56 férfi) AD beteganyagot vizsgáltak. D. pter.-re 86 beteg (44\%), macska epithelre $30(15 \%)$, füpollen keverékre $46(23,8 \%)$, nyírfa pollenre $10(16,7 \%)$, és fekete üröm pollenre $3(5 \%)$ beteg mutatott APT-ben pozitivitást (4. ábra). Az APT eredményei szignifikánsan korreláltak az anamnézissel, a Prick teszttel és specifikus IgE jelenlétével háziporatka, macska epithel és fúpollen esetén (24). A mi adataink alapján szoros korrelációt csak háziporatka esetében tudtunk kimutatni. 2004-ben szintén Darsow és mtsai publikálták egy 314, vegyes életkorú AD-s betegek (1,6-80 év, 177 nő és 137 férfi) bevonásával készült európai multicentrikus vizsgálat eredményeit. A betegek $89 \%$-a mutatott pozitivitást legalább 
egy aeroallergénre APT-ben. A D. pter. szenzibilizáció $39 \%$, nyírpollené $17 \%$, a fúpollenre $15 \%$ és a macskaepithelre $10 \%$-ban kaptak pozitív reakciót az APT-ben. A pozitív APT reakció korrelált az illető allergén Prick tesztben észlelt, vagy specifikus IgE vizsgálat során mért pozitivitásával. Az európai országokban más és más volt az aeroallergén szenzibilizáció mértéke, ami miatt az egyes régiókban eltérő allergén expozíció lehetôsége merült fel. Ennek ismeretében a kutatócsoport felvetette, hogy az egyes földrajzi régiókban más és más aeroallergén panellel kellene tesztelni az AD betegeket, ami viszont az APT standardizálásában okozna nehézségeket (25).

Saját eredményeink szerint az összes betegre vonatkoztatva a háziporatka szenzibilizáció 41,3\%-os (19/46), a pollen szenzibilizáció 54,3\%-os (25/46), a kutya hámszövet esetében 21,7\%-os (10/46) ill. a macska epithelnél 13\%-os (6/46) a szenzibilizáció gyakorisága. Tehát leggyakrabban a pollen szenzibilizáció fordult elő az általunk vizsgált $A D$ betegcsoportban, mely az irodalomban leírt értékeket helyenként jól közelíti. A kapott saját adatok szerint vegyes életkorú beteganyagban háziporatka és a macska szenzibilizáció az irodalmi adatoknak megfelelő, a pollen szenzibilizáció mértéke a saját vizsgálatunkban kis mértékben magasabb, mint az irodalmi adatoké; a kutya epithel szenzibilizációra nem áll rendelkezésre irodalmi adat.
A 18 évnél fiatalabb AD betegek vizsgálata során az APT-ben pozitivitás 8/14 (57\%) esetben volt igazolható. A háziporatka szenzibilizáció 18 éven aluliak között $42,8 \%$, a pollen szenzibilizáció szintén $42,8 \%$, a kutya és macska hámszövet szenzibilizáció 7,1-7,1\%. Hasonló publikációk alapján ekcémás gyermekek körében az aeroallergénekre adott pozitív reakció gyakorisága APT-vel 28,8-90\% (26, 27, 28, 29, 30). Az aeroallergén szenzibilizáció jelenlétének mértéke APT-vel a gyermek AD-s korcsoportban az irodalmi közlések alapján a következő: háziporatka szenzibilizáció $26,8-70 \%$, pollen szenzibilizáció adott pollen allergénekre 12,2-43\%, macska epithelé 0$25 \%$ és a kutya epithel szenzibilizáció $10-27 \%$ (26, 27 , 28), (4. ábra). Az általunk vizsgált gyermek betegcsoportban a háziporatka szenzibilizáció gyakorisága megfelel az irodalomban közölt szenzibilizáltsági értékeknek, pollen, kutya és macska epithel szenzibilizációra nem áll rendelkezésre elegendő irodalmi adat az összehasonlításhoz.

Magyarorzságon 2011-ben Pónyai és mtsai 37 felnőtt AD (28 nő, 9 férfi) beteg aeroallergén szenzibilizációját tanulmányozta APT segítségével. APT-vel késői pozitivitás 35\%-ban volt igazolható. A vizsgált összes betegre vonatkoztatva a háziporatka szenzibilizáció $18,9 \%$-os, a pollen szenzibilizáció 24,3\%-os, a macska epithel 8,1\%-os, a kutya epithel 13,5\%-os gyakoriság volt. Legnagyobb arányban a poratka pozitivitások bizonyultak relevánsnak (57\%) (31), (4. ábra).

\begin{tabular}{|c|c|c|c|c|c|c|}
\hline \multicolumn{2}{|c|}{ Korábbi közlemények/Saját adatok } & \multirow{2}{*}{\begin{tabular}{|l} 
APT \\
pozitivitás \\
$53 \%$
\end{tabular}} & \multirow{2}{*}{\begin{tabular}{|l}
$\begin{array}{l}\text { Háziporatka } \\
\text { szenziblizáció }\end{array}$ \\
$42,1 \%$ \\
\end{tabular}} & \multirow{2}{*}{\begin{tabular}{|l|}
$\begin{array}{l}\text { Pollen } \\
\text { szenziblizáció }\end{array}$ \\
$26,3 \%$ \\
\end{tabular}} & \multirow{2}{*}{$\begin{array}{l}\text { Macska epithel } \\
\text { szenzibilizáció }\end{array}$} & \multirow{2}{*}{\begin{tabular}{|l} 
Kutya epithel \\
szenziblizáció \\
\\
\end{tabular}} \\
\hline $\begin{array}{l}\text { vegyes korú } \\
A D-s \quad \text { beteg }\end{array}$ & $\begin{array}{l}\text { Darsow U. mtsai. } \\
\text { (23) }\end{array}$ & & & & & \\
\hline & $\begin{array}{l}\text { Darsow U. mtsai } \\
\text { (25) }\end{array}$ & & $44 \%$ & & $15 \%$ & \\
\hline & Saját adatok & $63 \%$ & $41,3 \%$ & $54,34 \%$ & $13 \%$ & $21,74 \%$ \\
\hline \multirow[t]{2}{*}{$\begin{array}{l}18 \text { éven felüli } \\
\text { AD-s betegek }\end{array}$} & $\begin{array}{l}\text { Pónyai Gy.mtsai } \\
\text { (31) }\end{array}$ & $35 \%$ & $18,9 \%$ & $24,3 \%$ & $8,1 \%$ & $13,5 \%$ \\
\hline & Saját adatok & $65,6 \%$ & $40,6 \%$ & $59,4 \%$ & $15,6 \%$ & $28,1 \%$ \\
\hline \multirow[t]{4}{*}{$\begin{array}{l}18 \text { éven aluli } \\
A D \text {-s betegek }\end{array}$} & $\begin{array}{l}\text { Wananukul S mtsai } \\
\text { (28) }\end{array}$ & $90 \%$ & $70 \%$ & & & \\
\hline & \begin{tabular}{|l}
$\begin{array}{l}\text { Boralevi F. mtsai } \\
\text { (27) }\end{array}$ \\
\end{tabular} & $89 \%$ & $66,5 \% \%$ & $17 \%$ & $0 \%$ & $10 \%$ \\
\hline & $\begin{array}{lll}\text { Cabon N. mtsai } \\
\text { (26) }\end{array}$ & $28,8 \%$ & $26,8 \%$ & & & \\
\hline & Saját adatok & $57 \%$ & $42,8 \%$ & $42,8 \%$ & $7,1 \%$ & $7,1 \%$ \\
\hline
\end{tabular}

Saját eredmények összehasonlítása korábbi közleményekkel 
A 18 éven felüli saját AD betegeinknél az APT pozitivitás 21/32 (65,6\%) esetben volt detektálható. A publikációk alapján a felnőtt AD betegek körében 30-53,9\% (32, 33, 34, 35, 36), az aeroallergén pozitív reakciók gyakorisága az APT tesztben, mely alacsonyabb, mint az általunk észlelt. Megfigyeléseink szerint 18 éven felüliek között a háziporatka szenzibilizáció gyakorisága 40,6\%, a pollen szenzibilizáció $59,3 \%$, a kutya hámszövet szenzibilizáció $28,1 \%$, a macska epithelé pedig 15,6\%. Az aeroallergén szenzibilizáció mértéke APT-vel a felnőtt AD-s betegcsoportban a publikációk szerint: háziporatka szenzibilizáció 18,9-47\%, pollen szenzibilizáció 22-24,3\%, macska epithelé $8,1-15,7 \%$ és a kutya epithel szenzibilizáció $13,5 \%$ értékek között változott $(32,33,34,35,36)$, (4. ábra). A saját eredmények alapján a felnőtt csoportban a háziporatka és a macska szenzibilizáció jelenléte az irodalmi adatoknak megfelelő, a pollen szenzibilizáció magasabb, mint az irodalmi adatok, a kutya epithel szenzibilizációra nem áll rendelkezésre elegendő irodalmi adat az összehasonlításhoz. A magasabb pollen szenzibilizáció mértéke a különböző földrajzi elhelyezkedés, valamint a pollenek különbözőségéból, továbbá a betegek klinikai tüneteinek különbségéből adódhat.

Pónyai és mtsai vizsgálatában a 37 általuk vizsgált ADs beteg közül 9 került az intrinsic, 28 az extrinsic csoportba. Az extrinsic csoportban a betegek 14\%-a poratka, $17,8 \%$-uk pollen, $10,7 \%$-uk macska, illetve kutya epithelre adott pozitív reakciót APT-ben. Extrinsic AD-ben a pozitív APT reakciók 46\%-ában volt igazolható korreláció az APT és a specifikus IgE eredmények és/vagy Prick tesztek között (31).

Tanulmányunkban mi is felosztottuk a $46 \mathrm{AD}$ beteget intrinsic és extrinsic csoportra. Az irodalmi adatokkal összhangban betegeink $15,2 \%$-a került az intrinsic, 84,7\%-a az extrinsic csoportba. Az extrinsic csoportban 71,8\%-ban (28/39) bizonyítottuk az aeroallergén szenzibilizációt, az intrinsic csoprotban 14\%-ban (1/7) APT-vel.

Megfigyeléseink szerint az atopiás dermatitis súlyossága, a SCORAD értékek alapján, nem befolyásolta az APT pozitív reakciók arányát, feltehetôen az alacsony betegszám magyarázhatja ezen eredményeket. Tudomásunk szerint, nem áll rendelkezésre közölt adat az APT pozitivitás és az AD súlyossága közti összefüggés vizsgálatára. Ismert azonban olyan tanulmány, amely az APT által kiváltott bőrreakció mértéke és az AD súlyossága közti összefüggést vizsgálta. Holm és mtsai vizsgálatukban úgy találták, hogy minél erősebb az APT által kiváltott bőrreakció, annál súlyosabbak az AD bőrtünetei (36).

A vizsgált $A D$ betegek több mint felében (63\%) detektáltunk egyéb atopiás betegséggel való társulást az anamnézisben, mely betegségek közül az allergiás rhinitis (80\%) fordult elő a legnagyobb gyakorisággal. A vizsgálatunkban kapott eredmények, mely szerint a férfiak $68,1 \%$ ánál, nőknél az esetek 45,8\%-ában társult az anamnézis alapján ismert egyéb atopiás betegség, mely adat jól korrelál az eddig publikált tanulmányokban ismertetett eredményekkel (29).
Az APT pozitivitást mutató betegek 69\%-ánál találtunk az anamnézisben egyéb atopiás megbetegedést. Az irodalmi adatok esetén ez a társult előfordulás az APT pozitivitás és az egyéb atopiás betegségek között 50 és 83\%-nak bizonyult $(28,36)$. Vizsgálatunkban az egyéb atopiás betegséggel rendelkezők csoportjában 75,8\%-ban találtunk APT pozitivitást.

Eredményeinket és az irodalmi adatokat figyelembe véve az APT-nek helye van az atopiás dermatitis diagnózisának felállításában, ahol a rutin diagnosztika hasznos és informatív módszerének tekinthető. További vizsgálatokra van azonban szükség, melyek az APT, a Prick teszt és a specifikus IgE meghatározás korrelációját vizsgálják adott allergénekre, és fontos megjegyezni, hogy az irodalomban szereplő adatok többsége csak a 18 éven aluli populációra vonatkozik. Érdemes a jövőben nagyobb beteganyagot felölelő, a felnőttkori AD sajátságait, valamint az erre a csoportra vonatkozó allergének együttes pozitivitását vizsgálni Prick teszttel, APT-vel és specifikus IgE meghatározással, valamint a súlyosság szerinti szenzibilizáció megoszlásának vizsgálata. Erről jelenleg kevés, kis betegszámot tartalmazó irodalmi adattokkal rendelkezünk.

\section{Köszönetnyilvánítás}

A munka elvégzéséhez az OTKA-K 108421. és a TÁMOP4.2.2.A-11/1/KONV-2012-0023 DEFENSE-NET pályázat nyújtott segítséget.

\section{IRODALOM}

1. Az Egészségügyi Minisztérium szakmai protokollja az atópiás dermatis ellátásáról, készítette: Bőr- és Nemibetegségek Szakmai Kollégiuma, Egészségügyi közlöny 2006. év 5. szám 2. kötet CD mellékletében

2. Levy R. M., Gelfand J. M., Yan A. C: The Epidemiology of atopic dermatitis. Clinics in Dermatol (2003) 21, 109-115.

3. Kuhnyár Á., Hunyadi L., Kósa L., Szabó I.: Az atópiás dermatitis előfordulási gyakorisának vizsgálata a Szabolcs-Szatmár-Bereg megyében élő 19 év alatti lakosok körében. Gyermekgyógyászat. (2005) 56 (4), 419-425.

4. Harangi F., Hartmann A., Lóriczy K., Scheider I., Sebók B.: Prevalence of atopic dermatitis in school children of Baranya county Orvosi Hetilap (2003) 144, 423-433.

5. Akiyama $M$.: FLG mutations in icthyosis vulgaris and atopic eczema: spectrum of mutations and population genetics. $\mathrm{Br} \mathrm{J}$ Dermatol (2010) 162(3), 472-7.

6. Kang K., Stevens S. R.: Pathophysiology of atopic dermatitis. Clinics in Dermatol (2003) 21, 116-121.

7. Mittermann I., Aichberger $K$. J., Bünder $R$. és mtsai: Autoimmunity and atopic dermatitis. Curr Opin Allergy Clin Immunol (2004) 4, 367-371.

8. Novak N., Bieber T.: Allergic and nonallergic forms of atopic diseases. J Allergy Clin Immunol (2003) 112, 252-262.

9. Kanokvalai Kulthanan, Kanonrat Boochangkool, Papapit Tuchinda, Leena Chularojanamontri: Clinical features of the extrinsic and intrinsic types of adult-onset atopic dermatitis, Asia Pac Allergy (2011) 1(2), 80-86.

10. Ott H., Stanzel S., Ocklenburg C., Merk H-F, Baron J. M. Lehmann S.: Total Serum IgE as a Parameter to Differentiate Between Intrinsic and Extrinsic Atopic Dermatitis in Children, Acta Derm Venereol (2009) 89, 257-261.

11. Hanifin J. M., Rajka G.: Diagnostic features of atopic dermatitis. Acta Derm Venereol, (1980) 92, 44-47.

12. Oranje A. P.: Practical issues on interpretation of scoring atopic dermatitis: SCORAD Index, objective SCORAD, patient-oriented SCORAD and Three-Item Severity score, Curr. Probl. Dermatol. (2011) 41, 149-155. 
13. Severity scoring of atopic dermatitis: the SCORAD index. Consensus Report of the European Task Force on Atopic Dermatitis, Dermatology (1993) 186(1), 23-31.

14. Schneider I., Sebók B., Harangi F.: Atopiás dermatitis, (2009)137-138, 207-211.

15. Kerschenlohr K., Darsow U., Burgdorf W. H., Ring J., Wollenberg A.: Lessons from atopy patch testing in atopic dermatitis, Curr Allergy Asthma Rep. (2004) 4, 285-289.

16. Rostenberg A., Sulzberger M. D.: Some results of patch tests Arch Dermatol, (1937) 35, 433-454.

17. Mitchell E. B., Crow J., Chapman M. D., Jouhal S. S. és mtsai: Basophils in allergen induced patch test sites in atopic dermatitis. Lancet (1982) 1, 127-130.

18. Adinoff A. D., Tellez P., Clark R. A.: Atopic dermatitis and aeroallergen contact sensitivity. J Allergy Clin Immunol, (1988) 81, 736-742.

19. Clark R. A., Adinoff A. D.: Aeroallergen contact can exacerbate atopic dermatitis: patch test as a diagnostic tool. J Am Acad Dermatol, (1989) 21, 863-869.

20. Ring J., Kunz B., Bieber T., Vieluf D., Przybilla B.: The ,atopy patch test" with aeroallergens in atopic eczema. J Allergy Clin Immunol (1989) 82, 195.

21. Darsow U., Vieluf D., Ring J.: Atopy patch test with differen vehicles and allergen concentrations: An approach to standardization. J Allergy Clin Immunol, (1995) 95, 677-684

22. Oldhoff J. M., Bihari I. C., Knol E. F., Bruijnzeel-Komen CAFM, Bruin-Weller M. S.: Atopy patch test in patients with atopic eczema/dermatitis syndrome: comparison of petrolatum and aqueous solution as a vehicle. Allergy, (2004) 59, 451-456.

23. Darsow U., Vieluf D., Ring J.: The atopy patch test: an increased rate of reactivity in patients who have an air-exposed pattern of atopic eczema. Br J Dermatol, (1996) 135, 182-186.

24. Darsow U., Laifaoui J., Kerschenlohr K., Wollenberg A. és mtsai: The prevalence of positive reactions in the atopy patch test with aeroallergens and food allergens in subjects with atopic eczema: a European multicenter study. Allergy (2004) 59, 1318-1325.

25. Darsow U., Vieluf D., Ring J.: Evaluating the relevance of aeroallergen sensitization in atopic eczema with the atopy patch test: a randomized, double-blind multicenter study. J Am Acad Dermatol (1999) 40, 187-193.

26. Cabon N., Ducombs G., Mortureux P., Perromat M., Taïeb A. Contact allergy to aeroallergens in children with atopic dermatitis: comparison with allergic contact dermatitis. Cont Derm, (1996) 35, 27-32.
27. Boralevi F., Hubiche T., Léauté-Labréze C. és mtsai: Epicutaneous aeroallergen sensitization in atopic dermatitis infants - determining the role of epidermal barrier impairment. Allergy (2008) 63, 205-210.

28. Wananukul S., Huiprasert P., Pongprasit P.: Eczematous skin reaction from patch testing with aeroallergens in atopic children with and without atopic dermatitis. Pediatr Dermatol, (1993) 10, 209-213.

29. Mortz C. G., Laurinsten J. M., Bindsley-Jensen C., Andersen K. $E$.: Prevalence of atopic dermatitis, asthma, allergic rhinitis, and hand and contact dermatitis in adolescents. The Odense Adolescence Cohort Study on Atopic Diseases and Dermatitis C.G. Mortz, Br J Dermatol (2001) 144, 523-532.

30. Schafer T., Heinrich J., Wjst M., Adam H., Ring J., Wichmann H. $E$.: Association between severity of atopic eczema and degree of sensitization to aeroallergens in schoolchildren. J Allergy Clin Immunol (1999) 104, 1280-1284.

31. Pónyai Gy., Máté B., Németh I., Kárpáti S., Temesvári E.: Az inhalatív atopy patch teszt szerepe az atópiás dermatitis diagnózisában. Bőrgyógyászati és Venerológiai Szemle (2011) 87. 3. 84-90.

32. Samochocki Z., Owczarek W., Zabielski S.: Can atopy patch test with aeroallergens be an additional diagnostic criterion for atopic dermatitis? Eur J Dermatol (2006) 16, 151-154.

33. Samochocki Z., Owzarek W., Rujna P., Raczka A.: Hypersensitivity to aeroallergens in adult patients with atopic dermatitis develops to the different immunological mechanism. Eur J Dermatol, (2007) 17, 520-524.

34. Goon A., Leow Y. H., Chan Y. H., Ng S. K., Goh C. L.: Atopy patch testing with aeroallergens in patients with atopic dermatitis and controls in Singapore. Clin Exp Dermatol, (2005) 30, 627631.

35. Pónyai Gy., Temesvári E., Kárpáti S.: Atópiás dermatitis felnôttkorban: epidemiológia, klinikai jellemzók, provokáló és prognosztikai faktorok. Orvosi Hetilap (2007) 148, 21-26.

36. Holm L., van Hage-Hamsten M., Ohman S., Scheynius A.: Sensitisation to allergens of house-dust mite in adults with atopic dermatitis in a cold temperature region. Allergy (1999) 54, 708715 .

Érkezett: 2014. 05. 15.

Közlésre elfogadva: 2014. 05. 29.

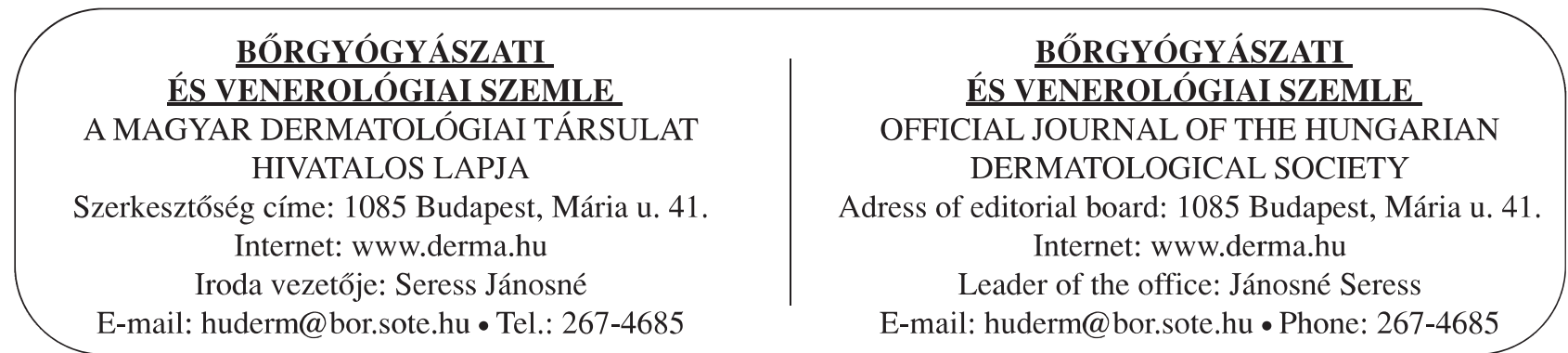

